\title{
Modelling Sustainability Agriculture and Economic Development in Indonesia
}

\author{
Agung Suwandaru, ${ }^{1, *}$, Thamer Alghamdi ${ }^{2}$ \\ ${ }^{1}$ School of Business, Western Sydney University - Bankstown Campus, Milperra, NSW, Australia \\ ${ }^{2}$ School of Business, Western Sydney University - Parramatta City Campus, Parramatta, NSW, \\ Australia
}

\begin{abstract}
Agriculture sustainability plays an essential role in country development. This paper aims to examine whether sustainable agriculture is beneficial to economic development in Indonesia. The empirical analysis employs the autoregressive distributed lag model over the data from 19612016. The results show that sustainable agriculture significantly contributes to economic development in the long run for both models. The gross fixed capital and rural population as endogenous variables show the positive relationship in the long run, but technical assistance shows negative results. In the short run, all variables show mixed results in different lags. These findings conclude that agricultural policies are broadly on the right track. However, the government needs to focus more on the agricultural bureaucracy and strengthen its infrastructure.
\end{abstract}

\section{Introduction}

Agriculture is one pillar of a country's economic development. Consequently, agricultural sustainability is needed to support the development to become sustainable. In this context, food security should be maintained to grease the wheels of the economy running. On the other hand, sustainable agriculture can be described as agricultural production of a country with the ability to fulfil the current needs and future generations. Moreover, farming in sustainable ways can use natural resources without harming the environment.

Indonesia is the best example of agricultural country which the agriculture sector can shape the domestic economy and keep food security walking together with a growing economy and massive population. This sector will provide food for the community, raw materials for industry, a source of labour, and capital formation needed by other sectors as a source of foreign exchange. The Indonesian government also has consistently placed agricultural policy as a strategic policy since the beginning of development up to the postreform period. Figure 1 illustrates Indonesia's gross domestic product (GDP) per capita and agricultural sustainability index. The GDP per capita is constantly increasing every year, as well as sustainable agriculture (the definition for variables will explain in the next section).

\footnotetext{
*Corresponding author: 19587312@student.westernsydney.edu.au
} 


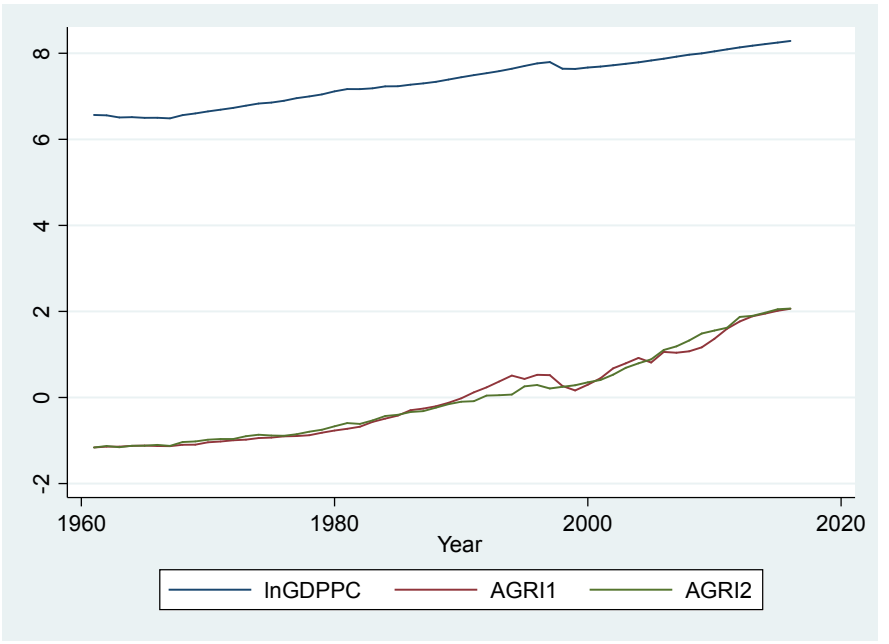

Fig. 1. Development of GDP per Capita and Sustainable Agriculture in Indonesia

Several studies have been conducted on the relationship between agriculture and economic development [1-4], however, the results were mix. Therefore, there is no standard reference for agriculture and economic development researchers. Furthermore, studies on agriculture especially in Indonesia are still very poorly explored, rendering the agricultural literature very limited. In this paper, we examine the relationship between agricultural sustainability and economic development using an econometric approach.

This paper covers the time from the beginning of development of Indonesia to the postreform period. The time period comprehensively captures the progress of development from old to modern era in Indonesia. We employ sustainable agriculture, economic development, and other variables such as gross fixed capital formation, technical assistance, and rural population as an integral part of the production function factors.

\section{A Brief History of Indonesian Agriculture}

Development of the agricultural sector in Indonesia cannot be separated from the nation's long history, both nationally and internationally. Agricultural alignments commenced with the Old Order because most people worked in the agricultural sector. Then, the agricultural development continued in a structured manner began after the New Order regime introduced the five-year development plan (Repelita) in 1969. The Repelita focused on food availability which became a prerequisite to accomplishing sustainable developments.

During the Repelita, international movement began to influence Indonesia's development such as the Green Revolution Movement. To bridge the international aspect, Indonesia government accommodated the green revolution movement by modernising the production tools and revitalising agricultural cultivation. The government invested and developed an agrarian modernisation program intending to increase agricultural production. There were four main efforts in increasing agricultural production: intensification, extensification, diversification, and agricultural rehabilitation [5]. The ultimate outcome of government investment in the agricultural sector was agricultural self-sufficiency for the first time in 1984. Food self-sufficiency is a strategic agricultural program because the availability of good quality food impacts the economy and the quality of human resources. After year of 1984, agricultural policy has always been a priority for the government 
through the Repelita until the last Repelita in 1994. Due to the change of political regime, Indonesia then switched to the Reformation Order.

In the Reformation era, agricultural policies focused on food availability and supporting farmers to compete in the global market. Farmers were expected to use resources efficiently and respond flexibly to the dynamics of changing commodity markets in the global economy [6]. The government pioneered the Independent Movement (GEMA) and a program to increase fishery product exports by 2003 in 2001. This program tried to increase agricultural production gradually from rice production, animal protein production, horticulture production, and rising exports of fishery products.

Indonesia has been experiencing with the change of government since reformation started. Every new government brought different agricultural policy perspectives and the political activity at the time increased the level of uncertainty around sustainability. In the recent time, the agriculture production showed a degradation when compare with the population growth. Sharma [7] conducted research on rice commodities during the period 2005-2015. This study found that Indonesia's rice production did not exceed the de minimise (less than 10\%). This was due to the growing population, and that most of them worked in the agricultural sector. In summary, the development of agriculture in Indonesia from 2000 to around 2020 has been experiencing a downward trend. This trend can be explained by the growing population, which requires the government to intervene by aiding the agricultural sector to maintain food security.

\section{Empirical Models}

The data used time-series data with spans from 1961 to 2016. Using this period, we will be able to cover the development of agriculture in Indonesia and its impact on economic development comprehensively from the early development to post-reformation era. Based on history - Indonesia's development started during the 1960s (old order) and has continued until the modern era (the start 1998).

Table 1. Data description

\begin{tabular}{|c|c|c|}
\hline Variable & Description & Source \\
\hline $\ln G D P P C$ & Natural logarithm of GDP per capita in constant 2010 US dollars. & World Bank \\
\hline $\ln G F C F$ & $\begin{array}{l}\text { Natural logarithm of gross fixed capital formation or gross domestic } \\
\text { fixed (infrastructure) investment }\end{array}$ & World Bank \\
\hline $\ln R U P O P$ & Natural logarithm of total rural population & World Bank \\
\hline $\ln T C G$ & $\begin{array}{l}\text { Natural logarithm of TCG which focuses on transferring technical } \\
\text { and managerial skills in technology. TCG purposes to build up } \\
\text { general capacity in specific investment projects including the } \\
\text { agriculture sector }\end{array}$ & World Bank \\
\hline lnRain & Rainfall precipitation & $\begin{array}{l}\text { Statistics } \\
\text { Bureau of } \\
\text { Indonesia }\end{array}$ \\
\hline Crop & Crop production index & World Bank \\
\hline Food & Food production index & World Bank \\
\hline Livestock & Livestock production index & World Bank \\
\hline lnFish & Natural logarithm of total fisheries production in metric tons & World Bank \\
\hline AGRII & $\begin{array}{l}\text { Sustainable agriculture extracted from the first principal component } \\
\text { analysis (PCA) of lnRain, Crop, Food, and Livestock. }\end{array}$ & $\begin{array}{l}\text { Author's } \\
\text { calculation }\end{array}$ \\
\hline$A G R I 2$ & $\begin{array}{l}\text { Sustainable agriculture extracted from the second PCA of InRain, } \\
\text { Crop, Food, and Livestock. }\end{array}$ & $\begin{array}{l}\text { Author's } \\
\text { calculation }\end{array}$ \\
\hline
\end{tabular}


The difficulty faced so far in this agriculture research field was research related still rarely carried out. This field research also has been the lack of complete data. Therefore, we contacted local bureau to complete the data. We calculated the provinces data became one strong balance time-series data. Table 1 show the data sources with the abbreviations.

The paper aims to be sufficiently comprehensive and to cover a long timeframe to provide a precise, thorough, and continuous analysis. To our knowledge, there is no research on agriculture and economic development with an econometric approach in the Indonesian context. We assume that the relationship between sustainable agriculture and economic development fits within an endogenous growth theory framework. This framework opines that economic development affects endogenous variables such as knowledge, the accumulation of human capital, and innovation, which are vital contributors to economic growth [8]. According to the theoretical consideration, the paper rests on the generalisation of development, and the connection to capital investment is debatable in the literature on developing countries. Consequently, there is no consensus on the relationship between them.

The endogenous growth framework claims that higher economic development can be promoted by higher incentives in social capital investment $[9,10]$. However, this argument does not explain how the proportion of social capital investment increases growth or development. The proportion (social, economic, community, culture, and security) of each country (as a subject of change) may have different impacts on economic development compared to other countries. On the other hand, we assume that Indonesia, as an agricultural country, has achieved development via the agriculture sector. Therefore, we include sustainable agriculture in the function that has impacted economic development following the Cobb-Douglas production function as equation (1) below [11].

$$
Y=f\left(A_{t} K_{t} L_{t} \operatorname{Agri}_{t}\right),
$$

where $t$ denotes time and $Y$ indicates the economic development variable. We employ gross domestic product per capita $(G D P P C)$ as a proxy of economic development. $A$ represents technological progress as affected by elements that contribute to efficiency and effectiveness. We postulate that technology and experiences are constant over time. Thus, an increase in physical capital does not affect the technology level. $K$ is physical and human capital with gross fixed capital formation $(G F C F)$ and technical grant cooperation (TCG) proxies following Bal, Dash [12]. $L$ and $A G R I$ denote labour forces and sustainable agriculture. We use the rural population as a proxy of labour input. All variables except $A G R I$ variables are converted to natural logarithm forms to minimise heteroskedasticity problems. $\beta 1, \beta 2, \beta 3$, and $\beta 4$ are the elasticity of each dependent variable. We derive Equation (1) to become Equation (2).

$\ln G D P P C_{t}=\beta+\beta_{1} \ln G F C F_{t}+\beta_{2} \ln T C G_{t}+\beta_{3} \ln R U P O P_{t}+\beta_{4} A G R I_{t}$

There are two analyses used; first, we posit agriculture sustainability covering a broad area from farming, husbandry, and fisheries to climate change (proxied by rainfall precipitation). To simplify, we develop sustainable agriculture indexes from the principal component analyses (PCA) to capture the various dynamic data. Second, we adopt the autoregressive distributed lag (ARDL) model to analyse dynamic relationships between variables with a single equation framework.

\subsection{Sustainable Agriculture Index}

We develop sustainable agriculture indexes for Indonesia from four indicators (InRain, Crop, Food, and Livestock) using the PCA. The indicators represent the agriculture sector 
comprehensively. It is necessary to include the various indicators in the PCA index calculation to generate robust index for agriculture. By applying the PCA analysis, we extracted several uncorrelated datasets into a multivariate statistic test [13]. Moreover, the PCA enables the capturing of a group of indicator variables that contribute to the sustainable agriculture index. Therefore, the index simplifies the dynamic variables used in the analysis [14]. Through the principal component (PC), we notice the proportion of the variables in the index formation. Therefore, we decide to take the two-highest PCs (PC1 and PC2) for deriving the indexes following the equation (1).

$$
A G R I_{P C_{s}}=\frac{\omega_{t}}{\omega_{\text {base }}} \times m
$$

$A G R I_{P C_{S}}$ denotes the sustainability agriculture indexes (constructed by $\mathrm{PC} 1$ and $\mathrm{PC} 2$ ). $\omega_{t, i}$ and $\omega_{\text {base }}$ represent the parameter values of InRain, Crop, Food, Livestock, and InFish which develop $A G R I_{P C_{S}} . m$ is a multiplier that can change following the $t$ year. Table 2 shows the weights from each component for each variable in the index formation.

Table 2. The Variable Weights of Sustainable Agriculture

\begin{tabular}{|l|l|l|l|l|l|}
\hline & lnRain & Food & Crop & Livestock & lnFish \\
\hline PC1 & 0.1037 & 0.4984 & 0.4981 & 0.4959 & 0.4968 \\
\hline PC2 & 0.9937 & -0.0373 & -0.0297 & -0.0861 & -0.0542 \\
\hline \multicolumn{2}{|l}{ Note: PC1 contributes $80 \%$ and PC2 contributes $19 \%$ in the index formation. }
\end{tabular}

Note: PC1 contributes $80 \%$ and PC2 contributes $19 \%$ in the index formation.

$\operatorname{Agri}_{P C_{S}}$ indexes are gauged by multiplication of variable weights of components at the same level and multiplier values of sustainable agriculture variables $\left(M_{P C 1,1}\right.$ to $M_{P C 1, t} ; M_{P C 2,1}$ to $\left.M_{P C 2, t}\right)$. Finally, the index scalars are treated as inner indexes $\left(\omega_{P C_{s}, t}\right)$ as shown in equation (2).

$\omega_{P C_{s}, t, i}=P C_{s, 1} M_{P C_{s}, 1}+P C_{s, 2} M_{P C_{s}, 2}+\cdots+P C_{s, t} M_{P C_{s}, t}=\sum_{i=1}^{t} P C_{s, t} M_{P C_{s}, t}$

\subsection{Unit Root Test}

Data can change and become a systemic problem if regressed. To solve the problem, a unit root test is needed to measure the stationarity of the data. We apply Augmented DickeyFuller (ADF) and Philip Perron (PP) unit root tests. The regression equation for the ADF is as follows.

$$
\Delta Y_{t}=\vartheta+\beta Y_{t-1}+\sum_{i=1}^{k} \pi_{i} \Delta Y_{t-1}+\varepsilon_{t}
$$

$Y_{t}$ indicates a targeted variable of $\mathrm{t}$ time. $\Delta$ denotes the 'first difference' form of the variable. $\vartheta$ and $\varepsilon$ are the constant and error terms. In ADF unit root test, a variable with a negative value and greater than the critical value does not have a unit root and is not stationary [15]. We also apply the Philip Perron test with the assumption; a variable that has a t-statistic higher than the critical value is called stationary. The determination of lag lengths on variables is based on the Akaike information criterion [16].

Table 3 explains that ADF and PP have different results on the stationary level. In the $\mathrm{ADF}$ test, three variables were stationary at the level, such as $\ln G F C F, \ln T C G$, and $\ln R U P O P$, while the $\ln G D P P C, A G R I 1$, and $A G R I 2$ variables were stationary at the first difference level. The significance of the ADF test explained that the $\ln G D P P C, \ln T C G$, and Agril variables reached a significance level of $1 \%$. However, the $\ln G F C F$ and $\ln R U P O P$ variables reached a significance level of $10 \%$. AGRI2 had significancy at $1 \%$. Different 
results were shown in the PP unit root test. The $\ln R U P O P$ variable was the only stationary variable at level. $\ln G D P P C, \ln G F C F$, $\ln R U P O P, A G R I 1$ and $A G R I 2$ variables were found to be stationary at the first difference level. All variables indicated significance at the $1 \%$ level. Thus, according to mix results in both unit root tests, we confirmed that implementing Autoregressive distributed lag (ARDL) bounds testing to the model.

Table 3. Unit Root Test Data

\begin{tabular}{|c|c|c|c|c|}
\hline Determinant & \multicolumn{2}{|c|}{ ADF } & \multicolumn{2}{|c|}{ PP } \\
\hline & Level & First Diff & Level & First Diff \\
\hline & T-stats & T-stats & T-stats & T-stats \\
\hline $\ln G D P P C$ & -0.523 & $-3.612 * * *$ & 0.505 & $-5.145^{* * *}$ \\
\hline $\ln G F C F$ & $-2.309 * *$ & NA & -0.902 & $-5.327 * * *$ \\
\hline $\ln T C G$ & $-7.478 * * *$ & NA & -2.430 & $-7.606 * * *$ \\
\hline $\ln R U P O P$ & $-3.077 * *$ & NA & $-6.492 * * *$ & NA \\
\hline AGRII & 1.532 & $-3.586 * * *$ & 1.816 & $-5.284 * * *$ \\
\hline AGRI2 & 0.847 & $-1.955^{*}$ & 3.484 & $-6.335 * * *$ \\
\hline \multicolumn{5}{|c|}{$\begin{array}{l}\text { Note: } *, * *, * * * \text { indicate } 1 \%, 5 \% \text { and } 10 \% \text { significancy. ADF unit root test } \\
\text { used intercept component time series. NA is no result in the unit root test } \\
\text { because the data is stationary in the previous integration level. }\end{array}$} \\
\hline
\end{tabular}

\subsection{ARDL Model}

The ARDL test is undertaken to determine whether there is cointegration between sustainable agriculture and the relevant variables as endogenous with economic growth. ARDL analysis simplifies the analysis because it does not require that all variables be integrated into the same order. This means the variables can be stationary in different orders (not up to the second difference). According to Gangopadhyay, Jain [17], Murthy and Okunade [18], the ARDL model has the following equation (6).

$$
\begin{aligned}
& \Delta \ln G D P P C_{t}= \\
& \quad \rho_{0}+\alpha_{1} \ln G D P P C_{t-1}+\alpha_{2} \ln G F C F_{t-1}+\alpha_{3} \ln T C G_{t-1}+\alpha_{4} \ln R U P O P_{t-1}+ \\
& \alpha_{5} A G R I_{P C_{s}, t-1}+\sum_{i=1}^{p} \delta_{i} \Delta \ln G D P P C_{t-i}+\sum_{i=1}^{q_{1}} \vartheta_{i} \Delta \ln G F C F_{t-i}+ \\
& \quad \sum_{i=1}^{q_{2}} \gamma_{i} \Delta \ln H C E_{t-i}+\sum_{i=1}^{q_{3}} \psi_{i} \Delta \ln R U P O P_{t-i}+\sum_{i=1}^{q_{4}} \eta_{i} \Delta \ln A G R I_{P C_{s}, t-i}+\varepsilon_{t},
\end{aligned}
$$

where $\rho_{0}$ is constant and $\varepsilon_{t}$ is white noise error. $\alpha_{1}, \alpha_{2}, \alpha_{3}, \alpha_{4}$, and $\alpha_{5}$ are long-run multipliers. $\delta_{i}, \vartheta_{i}, \gamma_{i}, \psi_{i}$, and $\eta_{i}$ denote short-run coefficient. $P C_{s}$ refers to the PC1 and PC2 agricultural sustainability indexes used in the model.

The ARDL model is suitable for estimating the short-run and long-run relationship on a small sample size. Moreover, this model can correct endogenous problems and their residuals simultaneously. A cointegration test with estimating bound test F-statistic was conducted to analyse the long-run relationship on the time series data. The null hypothesis for no cointegration is rejected if the F-statistic exceeds the upper critical bound value. The regression is inconclusive if the F-statistic is between the upper and lower bound values. There is no cointegration if the F-statistic is below the lower bound value. The equation below shows the existence of a long-run relationship.

$$
\begin{aligned}
\ln G D P P C_{t}= & \sigma_{0}+\sigma_{1} \sum_{i=1}^{p} \ln G D P P C_{t-1}+\sigma_{2} \sum_{i=1}^{q_{1}} \ln G F C F_{t-1}+\sigma_{3} \sum_{i=1}^{q_{2}} \ln T C G_{t-1}+ \\
& \sigma_{4} \sum_{i=1}^{q_{3}} \ln R U P O P_{t-1}+\sigma_{5} \sum_{i=1}^{q_{3}} A G R I_{P C_{s}, t-1}+\partial_{t}
\end{aligned}
$$

The short-run coefficients variables are constructed by an error correction term (ECT) following the Equation (8) below. 
$\triangle \ln G D P P C_{t}=$

$$
\begin{aligned}
& \varphi_{0}+\varphi_{1} \sum_{i=1}^{p} \Delta \ln G D P P C_{t-1}+\varphi_{2} \sum_{i=1}^{q_{1}} \Delta \ln G F C F_{t-1}+ \\
& \varphi_{3} \sum_{i=1}^{q_{2}} \Delta \ln T C G_{t-1}+\varphi_{4} \sum_{i=1}^{q_{3}} \Delta \ln R U P O P_{t-1}+ \\
& \varphi_{5} \sum_{i=1}^{q_{3}} \Delta A G R I_{P C_{s}, t-1}+n E C T_{t-1}+8_{t}
\end{aligned}
$$

where $E C T_{t-1}$ is equal with $\mathrm{Eq}(9)$

$$
\begin{aligned}
E C T_{t-1}= & \operatorname{lnGDPPC} C_{t}-\left(\sigma_{0}+\sigma_{1} \sum_{i=1}^{p} \ln G D P P C_{t-1}+\sigma_{2} \sum_{i=1}^{q_{1}} \operatorname{lnGFCF}_{t-1}+\right. \\
& \left.\sigma_{3} \sum_{i=1}^{q_{2}} \ln T C G_{t-1}+\sigma_{4} \sum_{i=1}^{q_{3}} \ln R U P O P_{t-1}+\sigma_{5} \sum_{i=1}^{q_{3}} A G R I_{P C_{s}, t-1}+\partial_{t}\right)
\end{aligned}
$$

The error correction term $(E C T)$ is the deviation in long-run equilibrium as adjusted gradually with short-run corrections. The ECT demonstrates the speed of adjustment on how quickly to restore the long-run equilibrium with a short-run shock. Coefficients on the short-run equation relate to the dynamic short-run convergence to the equilibrium model. Therefore, the ECT value should be in negative form (between 0 to 1 ) to indicate a long relationship.

Regarding to the model in Equation (9), we expect economic development to enhance sustainable agriculture with the other variables. Moreover, the decline in total rural population and the rise in growth would impact the increase of fixed capital formation.

\section{Results}

The research on the relationship between sustainability in agriculture and economic development in developing countries need to be explored. On the other hand, the existed research results remain mix [19-22]. Thus, this paper takes the scope of research in Indonesia because it has a consistently growing economy, even though the change of political regimes with different agricultural policy frameworks. As an agrarian country, it is natural that agriculture's contribution to the economy is substantial. Therefore, we try to analyse Indonesia's economic development, which is also reflected in economic growth, and whether there is a contribution of development and sustainability to agriculture by involving variables as a derivative of the production factor of Equation (1).

We applied time-series methods to analyse the relationship between sustainable agriculture and several other control variables with changes in economic growth using ARDL bounds testing. The ARDL bounds approach determined the cointegration between sustainable agriculture and other relevant variables in Indonesia. According to Shin, Yu [23], this approach is suitable for small samples and does not require all variables to be integrated at the same level to achieve stationarity.

The use of PCA on sustainable agriculture variables, which consists of several variables such as lnRain, Crop, Food, Livestock, and lnFish were suitable for simplifying variables and producing a solid robust index value that represents the constituent variables. We used two index numeric values derived from PC1 and PC2, which had more than one eigenvalue. The sustainable agriculture index value of $\mathrm{PC} 1$ produces a more dominant effect than the index value of PC2, so we focused more on the analysis results using PC1. On the other hand, the index value of PC2 supported and complemented the existence of PC1, so the PC2 index value was also essential to provide another model. Moreover, the analysis results using the PC2 index value could be compared to PC1 when interacting with the relevant variables in this study.

The empirical results of the relationship between sustainable agriculture and economic growth in Indonesia are presented in this section. Descriptive statistics for all variables are presented in Table 4 below. 
Table 4. Descriptive Statistics

\begin{tabular}{|l|l|l|l|l|}
\hline Variable & Mean & Std. Dev. & Min & Max \\
\hline $\ln G D P P C$ & 7.345258 & 0.554422 & 6.487694 & 8.286032 \\
\hline $\ln G F C F$ & 24.7447 & 1.311833 & 22.24703 & 26.53618 \\
\hline $\ln T C G$ & 18.73242 & 1.687895 & 14.31021 & 20.34353 \\
\hline $\ln R U P O P$ & 18.53471 & 0.144382 & 18.156 & 18.65451 \\
\hline$A G R I_{1}$ & $-6.62 \mathrm{E}-09$ & 1.000001 & -1.16214 & 2.063212 \\
\hline AGRI $_{2}$ & $-1.20 \mathrm{E}-08$ & 1.000001 & -1.16192 & 2.067913 \\
\hline
\end{tabular}

Table 5 exhibits the long-run estimation between economic growth and the determinant variables according to Equation (7). We constructed two different models in Equation (7); model 1 used the determinant variable AGRI1 from PC1, with the function of GDPPC = $f\left(G F C F, T C G, R U P O P, A G R I_{1}\right)$; and model 2 used the determinant variable AGRI2 from PC2 with the function of $G D P P C=f\left(G F C F, T C G, R U P O P, A G R I_{2}\right)$. The Bounds cointegration test on the two models showed that if the F-statistic value was greater than the upper and lower bound values, so we concluded that there were cointegration in the two models. Model 1 indicated that the F- statistic value was 2,470. This meant there was cointegration at the level of $10 \%$ significance. Model 2 with the F-statistic value 3.273 indicated that the model was cointegrated at the $1 \%$ significance level. The existence of cointegration in the models between time series data helped in analysing short-runs and a long-run relationship analysis on the factors that influence economic growth by including the agriculture variable in Indonesia.

Table 5. ARDL Bound Cointegration Test

\begin{tabular}{|l|l|l|l|l|l|l|l|l|l|}
\hline Model & F-stats & \multicolumn{2}{|c|}{$\mathbf{1 0 \%}$} & \multicolumn{2}{c|}{$\mathbf{5 \%}$} & \multicolumn{2}{c|}{$\mathbf{2 . 5 \%}$} & \multicolumn{2}{c|}{$1 \%$} \\
\hline & & $\begin{array}{l}\text { Lower } \\
\text { bounds }\end{array}$ & $\begin{array}{l}\text { Upper } \\
\text { bounds }\end{array}$ & $\begin{array}{l}\text { Lower } \\
\text { bounds }\end{array}$ & $\begin{array}{l}\text { Upper } \\
\text { bounds }\end{array}$ & $\begin{array}{l}\text { Lower } \\
\text { bounds }\end{array}$ & $\begin{array}{l}\text { Upper } \\
\text { bounds }\end{array}$ & $\begin{array}{l}\text { Lower } \\
\text { bounds }\end{array}$ & $\begin{array}{l}\text { Upper } \\
\text { bounds }\end{array}$ \\
\hline Model 1 & $2.470^{*}$ & 2.45 & 3.52 & 2.86 & 4.01 & 3.25 & 4.49 & 3.74 & 5.06 \\
\hline Model 2 & $3.273^{* * *}$ & 2.45 & 3.52 & 2.86 & 4.01 & 3.25 & 4.49 & 3.74 & 5.06 \\
\hline Notes & $*$ and *** are 10\%, and $2.5 \%$ significant level \\
\hline
\end{tabular}

We adopted the ARDL equation using the lag selection $(4,4,4,4,4,4)$ based on the Akaike information criterion (AIC) based on Eq. 6. Table 6 presents the ARDL estimation results with selection lags of 4,4,4,4,4 in Model 1 and Model 2. Both models 1 and 2 showed they have a positive and significant long-run relationship between GDP per capita and sustainability agriculture with different significance levels; such as, model 1 of $10 \%$ and model 2 of $5 \%$. These results showed that a positive relationship between GDP per capita and agricultural sustainability in this model supports the research of Kurniawan and Managi [24], Cumming and von Cramon-Taubadel [25], and Ahmed and Sallam [26]. In the short-run relationship analysis, sustainability agriculture showed negative results on GDP per capita.

Another variable with consistently positive and significant results in the long-run analysis in both models was the GFCF variable. In model 1, the GFCF variable has a significance level of $1 \%$, while in model 2 there was a significance level of $1 \%$. The results of this analysis were supported by Kanayo [27], Oded [28], and Adhikary [29]. In contrast, Hajamini and Falahi [30], state that GFCF has a weak relationship to GDP per capita. Thus, in the short-run analysis, GFCF has a mixed relationship to the formation of GDP per capita at different lags.

The technical assistance variable had a different long-run relationship from the other variables. This variable had a negative long-run relationship in both models. In addition, model 2 had a significance of 1\%. This result was in line with Phiri [31] who stated technical assistance becomes complex when it works in different field organisations. 
Corruption massively occurs in every state department in Indonesia [32] and it has impact to economic development $[33,34]$. The negative relationship in this paper results could explain how the complexity regarding social economy situation and corrupt environment in receiving technical assistance for development purposes.

Table 6. ARDL Estimation Results

\begin{tabular}{|c|c|c|c|c|c|c|c|}
\hline & \multirow[t]{2}{*}{ Variables } & \multicolumn{3}{|c|}{$\begin{array}{l}\text { Model 1 } \\
(G D P P C= \\
\left(G F C F, T C G, R U P O P, A G R I_{1}\right)\end{array}$} & \multicolumn{3}{|c|}{\begin{tabular}{l}
\multicolumn{1}{c}{ Model 2 } \\
$(G D P P C=$ \\
$f\left(G F C F, T C G, R U P O P, A G R I_{2}\right)$
\end{tabular}} \\
\hline & & Coefficient & SE & t-stats & Coefficient & SE & t-stats \\
\hline $\begin{array}{l}\text { Speed of } \\
\text { adjustment }\end{array}$ & $\triangle \operatorname{lnGDPPC}$ & $-0.5846 * *$ & 0.2199 & -2.66 & $-.7484 * * *$ & 0.2578 & -2.90 \\
\hline \multirow[t]{5}{*}{ Long-run } & $\mathrm{AGRI}_{1}$ & $0.1789 *$ & 0.0874 & 2.05 & & & \\
\hline & $\mathrm{AGRI}_{2}$ & & & & $0.1196^{* *}$ & 0.0517 & 2.31 \\
\hline & lnGFCF & $0.3566^{*}$ & 0.1390 & 2.56 & $0.4416^{* * *}$ & 0.0958 & 4.61 \\
\hline & lnRUPOP & \begin{tabular}{|l|l|}
0.1447 \\
\end{tabular} & 0.6376 & 0.23 & 0.2601 & 0.4708 & 0.55 \\
\hline & $\operatorname{lnTCG}$ & -0.0586 & 0.0513 & -1.14 & - & 0.0398 & -3.21 \\
\hline \multirow[t]{31}{*}{ Short run } & $\Delta \operatorname{lnGDPPC}(-1)$ & 0.0685 & 0.2006 & 0.34 & 0.0812 & 0.2089 & 0.39 \\
\hline & $\triangle \operatorname{lnGDPPC}(-2)$ & 0.0429 & 0.1862 & 0.23 & 0.0799 & 0.1818 & 0.44 \\
\hline & $\Delta \operatorname{lnGDPPC}(-3)$ & 0.0905 & 0.2011 & 0.45 & 0.1559 & 0.2115 & 0.74 \\
\hline & $\Delta \mathrm{AGRI}_{1}$ & -0.0141 & 0.0583 & -0.24 & & & \\
\hline & $\Delta$ AGRI $_{1}(-1)$ & -0.0591 & 0.0591 & -1.00 & & & \\
\hline & $\Delta \mathrm{AGRI}_{1}(-2)$ & -0.0426 & .0578 & -0.74 & & & \\
\hline & $\Delta$ AGRI $_{1}(-3)$ & 0.0311 & 0.0559 & 0.56 & & & \\
\hline & $\Delta \mathrm{AGRI}_{2}$ & & & & 0.0689 & 0.0793 & 0.87 \\
\hline & $\Delta$ AGRI $_{2}(-1)$ & & & & 0.0517 & 0.0706 & 0.73 \\
\hline & $\Delta \mathrm{AGRI}_{2}(-2)$ & & & & -0.0225 & 0.0691 & \begin{tabular}{|l|}
-0.33 \\
\end{tabular} \\
\hline & $\Delta \mathrm{AGRI}_{2}(-3)$ & & & & \begin{tabular}{|l|}
-0.0484 \\
\end{tabular} & 0.0886 & -0.55 \\
\hline & $\Delta \operatorname{lnGFCF}$ & 0.0678 & 0.1204 & 0.56 & 0.0223 & 0.1256 & 0.18 \\
\hline & $\Delta \operatorname{lnGFCF}(-1)$ & -0.0884 & 0.0904 & \begin{tabular}{|l|}
-0.98 \\
\end{tabular} & -.1053 & 0.0951 & \begin{tabular}{|l|}
-1.11 \\
\end{tabular} \\
\hline & $\Delta \operatorname{lnGFCF}(-2)$ & -0.0279 & 0.0649 & -0.43 & \begin{tabular}{|l|}
-.0139 \\
\end{tabular} & 0.0633 & $\mid-0.22$ \\
\hline & $\Delta \operatorname{lnGFCF}(-3)$ & 0.0237 & 0.0591 & 0.40 & 0.0161 & 0.0591 & 0.27 \\
\hline & $\Delta \operatorname{lnRUPOP}$ & 5.6489 & 4.9820 & 1.13 & 4.0744 & 4.6206 & 0.88 \\
\hline & $\Delta \operatorname{lnRUPOP}(-1)$ & -1.1527 & 4.7876 & -0.24 & -3.4289 & 5.0975 & -0.67 \\
\hline & $\Delta \operatorname{lnRUPOP}(-2)$ & -1.1106 & 3.9839 & -0.28 & -0.7011 & 3.6582 & -0.19 \\
\hline & $\Delta \ln R U P O P(-3)$ & -3.8775 & 2.8969 & -1.34 & -3.306 & 2.6787 & -1.23 \\
\hline & $\Delta \ln T C G$ & 0.0252 & 0.03319 & 0.76 & $0.0596^{*}$ & 0.0326 & 1.82 \\
\hline & $\Delta \operatorname{lnTCG}(-1)$ & 0.0298 & 0.0327 & 0.91 & $0.0589 *$ & 0.0320 & 1.84 \\
\hline & $\Delta \operatorname{lnTCG}(-2)$ & 0.0125 & 0.0263 & 0.47 & 0.0265 & 0.0255 & 1.04 \\
\hline & $\Delta \operatorname{lnTCG}(-3)$ & -0.0033 & 0.0201 & -0.17 & 0.0132 & 0.0219 & 0.60 \\
\hline & Constant & -1.7733 & 5.3038 & -0.33 & \begin{tabular}{|l|}
-4.4789 \\
\end{tabular} & 4.6847 & -0.96 \\
\hline & Observation & 52 & & & 52 & & \\
\hline & R squared & 0.8317 & & & 0.8389 & & \\
\hline & Adj R squared & 0.6822 & & & \begin{tabular}{|l|}
0.9988 \\
\end{tabular} & & \\
\hline & Log likelihood & 150.4225 & & & 151.5477 & & \\
\hline & Bgodfrey & 0.8786 & & & 0.1545 & & \\
\hline & Durbin-Watson & 2.0117 & & & 1.9766 & & \\
\hline & \begin{tabular}{|l|} 
White test \\
\end{tabular} & 0.4347 & & & 0.4347 & & \\
\hline
\end{tabular}


On the other hand, research with a positive relationship results between technical assistance and economic development in the short run for both models showed before two lags. This is consistent with Dornan and Pryke [35], Museru, Toerien [36], and Hidayat and Virgianita [37].

The variable rural population had a positive long-run relationship to GDP per capita in models 1 and 2. This meant that the population in rural areas had an essential role in GDP. This finding is consistent with Cai and Lu [38], Sharif Shofirun Sharif, Muhamad Rizal [39], and Asumadu-Sarkodie and Owusu [40]. Short-run analysis showed positive results in the first lag in both models, but in the lag two and the subsequent lags showed negative effects in both models. The Breusch-Godfrey LM test in Table 6 showed no serial autocorrelation in the models. model 1 , with a probability value of 0.8786 , and model 2 , with a probability value of 0.1545 , were greater than 0.05 , Hence, it could be concluded that there was no serial autocorrelation in the two models. While the white test with a probability value of 0.4347 for both models 1 and 2 demonstrated that we could not reject the null hypothesis or there was homoscedasticity between variables.

\subsection{Robustness Checks}

This section discusses the stability checks for models 1 and 2 . We used the cumulative sum of recursive residuals (CUSUM) and the cumulative sum of squared of recursive residuals (CUSUMSQ) to test the stability of the ARDL model $(4,4,4,4,4)$. According to Maravelakis [41], CUSUM and CUSUMSQ analyse parameter stability in the long-run and short-run analysis of the equation model. Ali, Zhang [42] explain that the stability test can be used as the residual in the error correction model. Moreover, both CUSUM and CUSUMSQ do not require the breakpoints determination in regressions. The Indonesian economy have experienced spikes of ups and downs during the paper period. Using these stability checks, we can detect structural breaks (changes in development economy) in the models to know the coherence between variables in the short-run and long-run estimates. Figures 1 and 2 illustrate CUSUM and CUSUMSQ for equation (7) for the model 1 $G D P P C=f\left(G F C F, T C G, R U P O P, A G R I_{1}\right)$ which uses the variable AGRI1 from PC1 (representing a proportion of $80 \%$ of those forming the Sustainable agriculture index). Figures 3 and 4 plot CUSUM and CUSUMSQ for equation (7) and for model 2 GDPPC = $f\left(G F C F, T C G, R U P O P, A G R I_{2}\right)$ using the variable AGRi2 from PC2 (representing the proportion of $20 \%$ of the builders of Sustainable agriculture index). Figures 1 and 2 illustrate that model 1 shows that there is a long-run relationship between variables in the $5 \%$ critical bounds test and confirms the stability of the model coefficients.

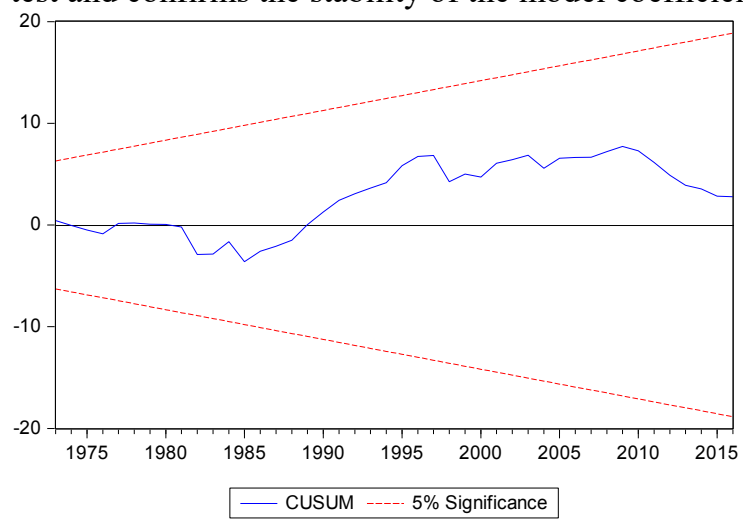

Fig 2. Plot of CUSUM for Model 1 with ARDL $(4,4,4,4,4)$ Model 
On the other hand, figures 3 and 4 present model 2, which is the extended ARDL model. They also showed stability in the Indonesian economy despite a slight deviation during the study period.

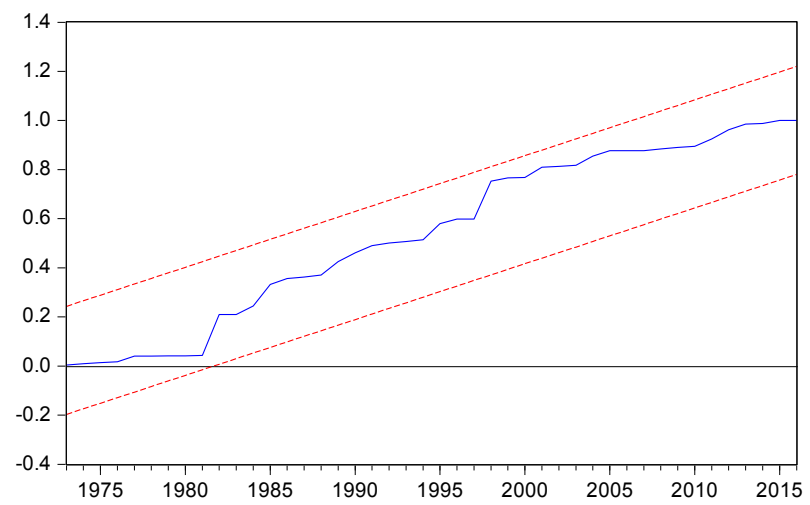

Fig 3. Plot of CUSUMSQ for Model 1 with ARDL $(4,4,4,4,4)$ Model

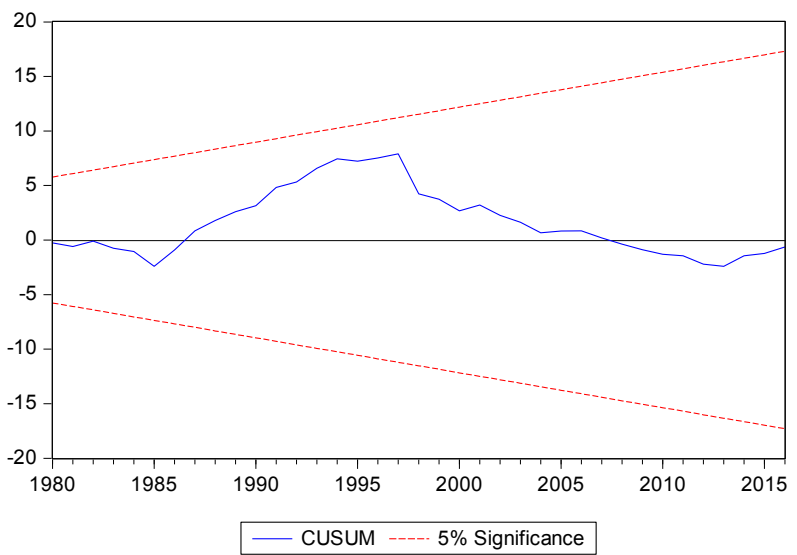

Fig 4. Plot of CUSUM for Model 2 with ARDL $(4,4,4,4,4)$ Model

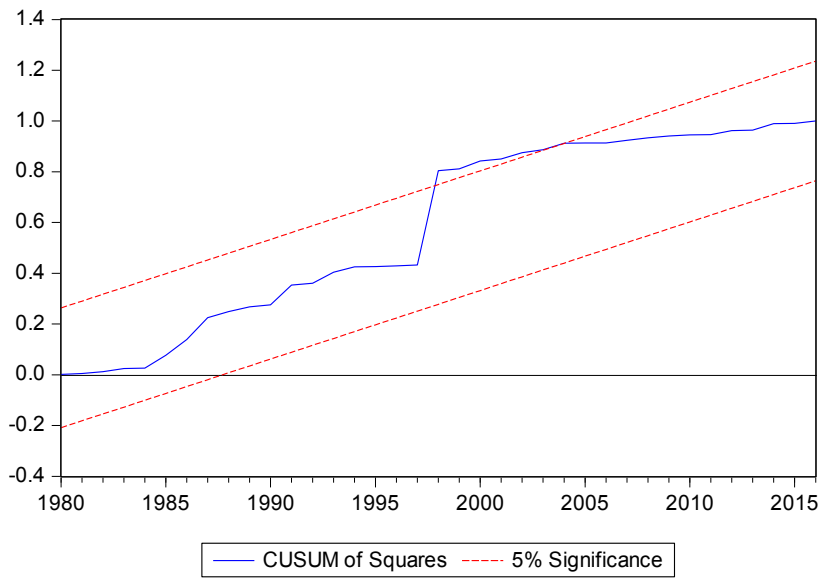

Fig 5. Plot of CUSUMSQ for Model 2 with ARDL $(4,4,4,4,4)$ Model 


\section{Conclusion}

Many studies reveal that success in agriculture has a significant impact on economic development. This result indicates that development in the agricultural sector is essential for an agricultural country like Indonesia. We access data over a long duration to cover the development of political regimes. As a result, the approaches of different regimes to development policies do not degrade the development in the agricultural sector, which indicating that agricultural sustainability occurs well. This consistency can be proven in the PCA analysis results on the value of eigenvectors PC1. The contribution variables in PC1 shows that the contribution of the variable food production index, crop production index, livestock production index, and the amount of fish production consistently has a more prominent and positive proportion of the sustainable agricultural index. Meanwhile, natural factors are dominant in forming the sustainability index agriculture value in PC2.

The analysis results using the ARDL technique show that the Indonesian government's alignment with the development of agricultural sector. Sustainability agriculture in a longterm relationship has a positive and significant impact on economic development. In conclusion, the Indonesian people enjoy implementing Law Number 5 of 1960 concerning basic regulations on agrarian principles through economic development throughout the research period 1961 to 2016 .

The variable gross fixed capital also made a positive and significant contribution to economic development in both models. This variable shows that Indonesia's capital for development is very large, so it positively impacts development. Likewise, the population in rural areas (as the main driver of agriculture) also plays a positive role in development. The role of the rural population is also consistent in models 1 and 2. However, the longterm relationship of technical assistance to economic development is negative. This analysis reveals that as a multicultural and developing country, Indonesia still has problem with an ineffective bureaucracy. This bureaucratic problem may be related to corruption $[43,44]$, which, although gradually improved since the establishment of a Corruption Eradication Commission (KPK), has not been established for a long time. The period covering early development until the post-reform era reveals that the political oligarchy during the new order (which covered more than half of the research duration) brought a corruption bias [45]. This affect to the technical assistance in agricultural sector. As a result, this variable has a negative relationship with economic development. Future research can focus on the contribution of corruption in the agricultural sector in other developing countries.

\section{References}

1. Cole, S.A. and W. Xiong, Agricultural insurance and economic development. Annual Review of Economics, (2017). 9: p. 235-262.

2. Galor, O. and Ö. Özak, The Agricultural Origins of Time Preference. American Economic Review, (2016). 106(10): p. 3064-3103.

3. Kirchner, M., et al., Ecosystem services and economic development in Austrian agricultural landscapes - The impact of policy and climate change scenarios on trade-offs and synergies. Ecological Economics, (2015). 109: p. 161-174.

4. Schneider, U.A., et al., Impacts of population growth, economic development, and technical change on global food production and consumption. Agricultural Systems, (2011). 104(2): p. 204-215. 
5. Abraham, M. and P. Pingali, Transforming Smallholder Agriculture to Achieve the SDGs, in The Role of Smallholder Farms in Food and Nutrition Security, S. Gomez y Paloma, L. Riesgo, and K. Louhichi, Editors. (2020), Springer International Publishing: Cham. p. 173-209.

6. Solahuddin, S., Pembangunan Pertanian Era Reformasi. Departemen Pertanian, Jakarta, (1999).

7. Sharma, S.K., Indonesia: Product Specific Support to Rice Under WTO, in The WTO and Food Security: Implications for Developing Countries. (2016), Springer Singapore: Singapore. p. 81-91.

8. Jones, C.I., Paul Romer: Ideas, Nonrivalry, and Endogenous Growth. The Scandinavian Journal of Economics, (2019). 121(3): p. 859-883.

9. Rangongo, M.F. and C.C. Ngwakwe, Human Capital Investment and Economic Growth: A Test of Endogenous Growth Theory in Two Developing Countries. Acta Universitatis Danubius. Oeconomica, (2019). 15(1).

10. Hunt, S.D., Understanding the Drivers of Economic Growth: Grounding Endogenous Economic Growth Models in Resource-Advantage Theory. Contemporary Economics, (2012). 6(4): p. 4.

11. Kleyn, J., et al., Preliminary testing of the Cobb-Douglas production function and related inferential issues. Communications in Statistics - Simulation and Computation, (2017). 46(1): p. 469-488.

12. Bal, D.P., D.P. Dash, and B. Subhasish, The effects of capital formation on economic growth in India: Evidence from ARDL-bound testing approach. Global Business Review, (2016). 17(6): p. 1388-1400.

13. Asbahi, A.A.M.H.A., et al., Novel approach of Principal Component Analysis method to assess the national energy performance via Energy Trilemma Index. Energy Reports, (2019). 5: p. 704-713.

14. Bro, R. and A.K. Smilde, Principal component analysis. Analytical Methods, (2014). 6(9): p. 2812-2831.

15. Paparoditis, E. and D.N. Politis, The asymptotic size and power of the augmented Dickey-Fuller test for a unit root. Econometric Reviews, (2018). 37(9): p. 955-973.

16. Vrieze, S.I., Model selection and psychological theory: a discussion of the differences between the Akaike information criterion (AIC) and the Bayesian information criterion (BIC). Psychol Methods, (2012). 17(2): p. 228-43.

17. Gangopadhyay, P., S. Jain, and A. Suwandaru, What Drives Urbanisation in Modern Cambodia? Some Counter-Intuitive Findings. Sustainability, (2020). 12(24): p. 10253.

18. Murthy, V.N.R. and A.A. Okunade, Determinants of U.S. health expenditure: Evidence from autoregressive distributed lag (ARDL) approach to cointegration. Economic Modelling, (2016). 59: p. 67-73.

19. Mishra, P. and D. Dash, Rejuvenation of biofertilizer for sustainable agriculture and economic development. Consilience, (2014)(11): p. 41-61.

20. Jorgenson, D.W., The role of agriculture in economic development: Classical versus neoclassical models of growth. (2017): Routledge.

21. Jatuporn, C., et al., Does a long-run relationship exist between agriculture and economic growth in Thailand. International Journal of Economics and Finance, (2011). 3(3): p. 227-233. 
22. Dürr, J., The political economy of agriculture for development today: the "small versus large" scale debate revisited. Agricultural Economics, (2016). 47(6): p. 671681.

23. Shin, Y., B. Yu, and M. Greenwood-Nimmo, Modelling asymmetric cointegration and dynamic multipliers in a nonlinear ARDL framework, in Festschrift in honor of Peter Schmidt. (2014), Springer. p. 281-314.

24. Kurniawan, R. and S. Managi, Economic Growth and Sustainable Development in Indonesia: An Assessment. Bulletin of Indonesian Economic Studies, (2018). 54(3): p. 339-361.

25. Cumming, G.S. and S. von Cramon-Taubadel, Linking economic growth pathways and environmental sustainability by understanding development as alternate socialecological regimes. Proceedings of the National Academy of Sciences, (2018). 115(38): p. 9533.

26. Ahmed, O. and W. Sallam, Studying the volatility effect of agricultural exports on agriculture share of GDP: The case of Egypt. African Journal of Agricultural Research, (2018). 13(8): p. 345-352.

27. Kanayo, O., The Impact of Human Capital Formation on Economic Growth in Nigeria. Journal of Economics, (2013). 4(2): p. 121-132.

28. Oded, G., Chapter 5 - Inequality, Human Capital Formation, and the Process of Development, in Handbook of the Economics of Education, E.A. Hanushek, S. Machin, and L. Woessmann, Editors. (2011), Elsevier. p. 441-493.

29. Adhikary, B.K., FDI, trade openness, capital formation, and economic growth in Bangladesh: a linkage analysis. International Journal of Business and Management, (2011). 6(1): p. 16.

30. Hajamini, M. and M.A. Falahi, Economic growth and government size in developed European countries: A panel threshold approach. Economic Analysis and Policy, (2018). 58: p. 1-13.

31. Phiri, M.W., The impact of aid on the economic growth of developing countries (LDCs) in Sub-Saharan Africa. Gettysburg Economic Review, (2017). 10(1): p. 4.

32. Pertiwi, K. and S. Ainsworth, "Democracy is the Cure?": Evolving Constructions of Corruption in Indonesia 1994-2014. Journal of Business Ethics, (2020): p. 1-17.

33. Liu, Y. and F. Dong, Corruption, Economic Development and Haze Pollution: Evidence from 139 Global Countries. Sustainability, (2020). 12(9): p. 3523.

34. Saha, S. and M.S. Ben Ali, Corruption and Economic Development: New Evidence from the Middle Eastern and North African Countries. Economic Analysis and Policy, (2017). 54: p. 83-95.

35. Dornan, M. and J. Pryke, Foreign Aid to the Pacific: Trends and Developments in the Twenty-First Century. Asia \& the Pacific Policy Studies, (2017). 4(3): p. 386-404.

36. Museru, M., F. Toerien, and S. Gossel, The impact of aid and public investment volatility on economic growth in Sub-Saharan Africa. World Development, (2014). 57: p. 138-147.

37. Hidayat, A. and A. Virgianita, Technical assistance for innovation development from and to developing country: Case study of Indonesia's foreign aid to Timor-Leste. International Journal of Development Issues, (2019).

38. Cai, F. and Y. Lu, Population Change and Resulting Slowdown in Potential GDP Growth in China. China \& World Economy, (2013). 21(2): p. 1-14. 
39. Sharif Shofirun Sharif, A., R. Muhamad Rizal, and A. Awang, The Nexus of Population, GDP Growth, Electricity Generation, Electricity Consumption and Carbon Emissions Output in Malaysia. International Journal of Energy Economics and Policy, (2020). 10(3): p. 84-89.

40. Asumadu-Sarkodie, S. and P.A. Owusu, A multivariate analysis of carbon dioxide emissions, electricity consumption, economic growth, financial development, industrialization, and urbanization in Senegal. Energy Sources, Part B: Economics, Planning, and Policy, (2017). 12(1): p. 77-84.

41. Maravelakis, P.E., Measurement error effect on the CUSUM control chart. Journal of Applied Statistics, (2012). 39(2): p. 323-336.

42. Ali, S., et al., Impact of electricity consumption on economic growth: an application of vector error correction model and artificial neural networks. The Journal of Developing Areas, (2020). 54(4).

43. Kasim, A., Bureaucratic Reform and Dynamic Governance for Combating Corruption: The Challenge for Indonesia. Bisnis \& Birokrasi, (2013). 20(1): p. 18-22.

44. Prabowo, H.Y., R. Hamdani, and Z. Mohd Sanusi, The new face of people power: an exploratory study on the potential of social media for combating corruption in Indonesia. Australasian Accounting, Business and Finance Journal, (2018). 12(3).

45. Quah, J.S.T., Singapore's Corrupt Practices Investigation Bureau. Asian Education and Development Studies, (2015). 4(1): p. 76-100.

\section{Appendix}

Apendix 1. Sustainable Agriculture Eigenvalues

\begin{tabular}{|l|l|l|}
\hline Variable & PC1 & PC2 \\
\hline InRain & 0.1037 & 0.9937 \\
\hline Crop & 0.4984 & -0.0373 \\
\hline Food & 0.4981 & -0.0297 \\
\hline Livestock & 0.4959 & -0.0861 \\
\hline lnFish & 0.4968 & -0.0542 \\
\hline
\end{tabular}

Notes: The values above are correlation results based on principal components 1 and 2 